\title{
PROVOKASI VISUAL DALAM LUKISAN
}

\author{
Fuad Ardi Nugraha \\ fuadardinugraha@gmail.com
}

\begin{abstract}
Abstrak
Praktik melukis selain dimaknai sebagai kebebasan berekspresi secara pribadi, terbuka suatu kemungkinan dapat mengemban fungsi sosial sebagai kepedulian pembelajaran dan penyadaran masyarakat. Fenomena kehidupan kehidupan sosial politik dengan berbagai penyimpangan nilainilai moral dan etika kemanusiaan merupakan realitas kegelisahan yang menarik untuk di respon sebagai ide penciptaan karya lukisan. Metode penciptaan karya lukisan dilakukan melalui beberapa prosedur yang diawali dengan proses pengamatan objek, eksplorasi pengolahan dan pencapaian bentuk-bentuk visual yang simbolik-provokatif kemudian divisualisasikan dengan menggunakan bahan tinta pada kanvas dengan teknik arsir. Proses interaksi antara seniman dan masyarakat terjadi melalui media lukisan. Melalui proses pengamatan, pemahaman dan penikmatan terhadap lukisan yang bernilai provokatif ada keterlibatan dan pemberdayaan sifat-sifat apresiatif, kritis, demokratis dan tanggung jawab yang bermakna sebagai proses pembelajaran dan penyadaran hidup bermasyarakat.
\end{abstract}

Kata kunci : lukisan, provokasi-visual, pembelajaran, penyadaran

\begin{abstract}
The practice of painting can be interpreted as a personal, liberat form of expression, yet it can also be interpreted as serving a social function, to educate and to raise the awareness of the society. The driving force of this creative work is a personal concern with the socio-political issues riven with moral and ethical deviation. The process started from observations of the object, exploration of methods and production of visual objects in the forms of ink on canvass. The interaction between an artist and the society occured on the paintings. The provocations inscribed in these work were meant to involve and empower the viewers by confronting their appreciation, critical view and responsibilities as members of society.
\end{abstract}

Keywords : painting, visual provocation, education, awareness

\section{Pendahuluan}

Berbagai permasalahan silih berganti, saat alam dilanda banjir, panas, kering, tanah longsor, gunung meletus, di sisi lain tatanan kehidupan sosial politik mengalami kekacauan. Hati saya menjadi resah ketika membaca koran karena di beberapa halamannya memuat berbagai peristiwa penyimpangan. Kejahatan merajalela, arogansi kesewenangan sering diperlihatkan oknum-oknum penguasa sebagai aparat pemaksa. Banyak orang mengatakan "jaman iki jaman edan, yen ora ngedan ora keduman".

Dari sampel tiga koran, yaitu Kedaulatan Rakyat, Kompas dan Republika yang diambil secara acak ditemukan berbagai kasus yang menarik untuk diperhatikan. Berita Republika (2 Maret 2015 :1) menyebutkan pada Januari dan Februari 2015, terdapat 48 kasus perampasan motor di wilayah Polda Metro Jaya yang ditangani. Sebanyak 29 orang ditangkap dan tujuh pelaku diantaranya meninggal. 
Di sisi lain realitas kekerasan, penganiayaan dan pemaksaan sering dilakukan oleh oknum-oknum penegak hukum yang mengubah nilai kepentingan umum menjadi kepentingan pribadi.

Harian Kompas (7 Desember 2014 : 2) memberitakan : Kuswanto, korban salah tangkap polisi dari kepolisian resort Kudus Jawa Tengah. Dua tahun yang lalu, ia sengaja dibakar sejumlah oknum polisi setempat karena menolak mengaku sebagai perampaok PT. Walls, Kudus. Matanya dilakban, kakinya diikat, tangannya diborgol kemudia disiram bensin dan dibakar.

Kehidupan nyata sehari-hari hanyalah dunia permukaan. Di balik permukaan mungkin dapat ditemukan adanya aspek realitas yang kadang sering bertentangan.

Berita Kedaulatan Rakyat (21 Juli 2011:1) menyebutkan sosok Nazarudin yang kontroversional. Di satu sisi, ia merupakan tersangka kasus suap pembangunan wisma atlet SEA GAMES XXVI di Jakabaring Palembang dan diduga terlibat korupsi di beberapa kasus. Namun di sisi lain melalui BBM dia mengungkapkan berbagai kasus kejahatan yang melibatkan orang lain yang bila terbukti bisa menimbulkan efek domino yang luar biasa.

Kasus ini berkelanjutan menunjuk dan menyeret berbagai pihak yang ikut terlibat sehingga ia tidak menjadi korban sendirian. Peristiwa kejahatan dilakukan oleh figurfigur yang mestinya selalu dihormati dan diteladani namun perilakunya lepas kontrol dan mengabaikan nilai-nilai moral kemanusiaan tanpa merasa salah.

Dunia politik seringkali ternoda karena sifat mengayomi masyarakat kurang nampak, sebaliknya sikap arogansi dan sewenang-wenang diperlihatkan sebagai kekuatannya. Harian Kompas (22 Februari 2015 : 3) memberitakan : "Penganiayaan wartawan harian Radar Bekasi, Randy Yasetiawan Priogo (27) dilakukan oleh oknum-oknum politisi di kota Bekasi.

Situasi dan kondisi negeri yang semakin labil membuat berbagai ketidakpuasan masyarakat yang kemudian terlampiaskan dalam berbagai bentuk kekerasan dan praktekpraktek penyelesaian masalah dengan main hakim sendiri. Amukan masa di berbagai tempat sebagai pelampiasan rasa kecewa sering terjadi. Salah satu contoh terjadi "seorang Polisi babak belur dihajar warga Desa Sendang Sari Kecamatan Lasem Kabupaten Rembang, Selasa (3/3) malam. (Kedaulatan Rakyat, 5 Maret 2015 : 18).

Realitas gejolak dalam kehidupan sosial politik yang semakin menggelisahkan dan banyak realitas yang saling bertentangan sungguh merupakan hal yang sensitif dan menarik bagi saya untuk diperhatikan karena menyangkut dan tidak dapat dipisahkan dari kepentingan hidup manusia bermasyarakat. Sedikit atau banyak akibat yang ditimbulkan dapat mengganggu sta- bilitas kehidupan yang diinginkan bersama. Harian Kompas (4 Oktober 2014 : 1) menyebutkan beragam kalangan meminta agar kegaduhan politik segera diakhiri. Manuver-manuver politik telah memberikan sinyal negatif ke pasar. Pasar keuangan diperkirakan akan tertekan hingga akhir tahun ini. Jika tidak ada perbaikan sitasi politik, investasi akan terganggu sehingga pertumbuhan rendah.

Dalam merespon berbagai kejadian demikian seniman dapat melakukan kepedulian dalam proses kehidupan bermasyarakat. Atas nama kreativitas maka berbagai tema kekinian dalam kehidupan sosial politik yang cenderung menggelisahkan dapat saya angkat sebagai rangsang penciptaan karya seni. Sebuah lukisan memungkinkan menjadi 
semacam catatatan yang merefleksikan berbagai kenyataan kehidupan manusia pada zamannya. Bahkan sebuah lukisan memungkinkan dapat dimanfaatkan dalam proses pembelajaran dan penyadaran sosial. "Salah satu aspek mendasar dari suatu karya seni adalah menggambarkan pengalaman keindahan dan ini merupakan kunci dalam proses pembelajaran" (M. Jazuli 2013 : 37). Hal demikian mendorong munculnya perkembangan seni menjadi lebih dinamis terkait dengan realitas kehidupan manusia sehari-hari. Popo Iskandar mengatakan : "seni ialah alat pengutaraan kongkrit suatu batin si penciptanya dalam kesadaran kehidupan berkelompok" (Sudarmaji 1979 : 7). Terdorong keinginan untuk berperan sosial, saya merasa perlu mempertimbangkan niali provokasi visual dalam lukisan.

Provokasi berasal dari bahasa inggris provokative berarti "yang merangsang untuk bertindak" (Andre Ardiansayah : 196). Provokasi visual merupakan bentuk provokasi melalui ungkapan visual (rupa), sebagai daya rangsang yang dapat membangkitkan tindakan tertentu atas suatu objek yang dihadapi melalui media rupa. Provokasi visual menjadi penting sebagai bentuk interaksi sosial antara seniman dengan masyarakat. "Dalam interaksi sosial, eksprei simbolik dan keindahan seni menjadi kebutuhan kolektif sehingga mampu berperan sebagai pengikat sosial dan menimbulkan solidaritas sosial" (M. Jazuli, 2013 : 48). Provokasi visual dalam lukisan merupakan rangsangan bagi seseorang dan masyarakat (apresian) untuk membangun pemahaman bersama dan berbuat sesuatu yang diyakini bermanfaat dalam kehidupan bersama.

Nilai provokasi visual dalam lukisan dapat diperoleh antara lain melalui tahapan proses simbolisasi, yaitu penggambaran sesuatu dengan memberikan makna terhadap objek-objek atau kejadian-kejadian. Simbolisasi saya lakukan melalui proses penggubahan bentuk sedemikian rupa sebagai presentasi suatu makna. Penggubahan bentuk tidak harus mengacu pada keindahan tertentu tetapi lebih mengutamakan efek makna yang mewakili ide dan emosi. Selain sebagai pengungkapan nilai ekspresi, suatu lukisan yang bernilai provokatif memungkinkan dapat berfungsi dalam proses pembelajaran dan penyadaran kehidupan sosial politik masyarakat pada zamannya.

\section{Tinjauan Seni Lukis}

Karya seni diciptakan karena beberapa dorongan atau motivasi yang mungkin berbeda antara yang satu dengan yang lain. Ada yang lahir karena keinginan manusia akan hal-hal yang indah ada yang karena kehendak manusia untuk berkomunikasi dengan sesama serta ada pula yang didorong oleh desakan untuk memenuhi kebutuhan sehari-hari (Soedarso Sp, 2006:101). Menurut Nooryan Bahari (2008:14) bahwa karya seni dibuat atau diciptakan bukan sekedar untuk ditampilkan, dilihat dan didengarkan saja tetapi harus penuh dengan gagasan, abstraksi, pendirian, pertimbangan, hasrat, kepercayaan serta pengalaman tertentu yang hendak dikomunikasikan pencapaiannya. Lebih spesifik teori Platon mengatakan : "hanya seni yang mampu mengajari manusia untuk mengendalikan nafsunya, untuk menjalani hidup dengan kebajikan serta mencari kebenaran, barulah seni itu mempunyai makna (Michael Houskaller, 2015:14). Demikian luasnya wilayah pemahaman teori tentang seni yang kemungkinan dapat saling berbeda atau saling melengkapi. M. Dwi Marianto (2011: 17) memberikan penjelasan : 
"Seni selalu - secara langsung maupun tidak - merefleksi kebutuhan, politik, prioritas- prioritas, dan selera dari seniman bersangkutan; pun mencerminkan institusi-institusi yang mendukung dan menyebarluaskan karya seniman itu, serta dunia sosial-budaya dimana seniman dan institusi bersangkutan jadi bagian dari kehidupan keseluruhan."

Dari uraian penjelasan tersebut di atas menunjukkan bahwa suatu karya seni diciptakan tidak sembarangan, demikian pula yang terjadi pada penciptaan karya lukisan. Ada dorongan atau motivasi tertentu yang menuntun dari awal sampai akhir dengan berbagai pertimbangan sehingga pencapaiannya dapat dikomunikasikan atau dinikmati sesuai dengan tujuannya.

Seni lukis adalah suatu pengucapan pengalaman artistik yang ditumpahkan dalam bidang dua dimensional dengan menggunakan garis dan warna (Soedarso Sp, 1976 : 7).

Namun secara umum lukisan dikenal dengan sapuan warna-warna cat minyak di atas kanvas dan cat air di atas kertas menggunakan berbagai jenis kuas, walaupun dalam perkembangannya media lukisan tidak terbatas pada cat minyak dan cat air saja tetapi dengan berbagai bahan pewarna dan elemen-elemen lainnya sesuai dengan ide dan gagasan penciptanya (Nooryan Bahari, 2008:15).

Pengertian lukisan menjadi beragam, namun dari aspek media visualnya ada kecenderungan bersifat dua dimensional dengan berbagai kemungkinan jangkauan materialnya seperti cat minyak, cat air, pastel, tinta, kertas, kanvas dan berbagai aplikasi yang memberi kemungkinan untuk mewujudkan media rupa. Dari aspek wujud yang nampak ada unsur garis, warna, tekstur dan lain sebagainya yang tersusun sedemikian rupa dengan kaidah-kaidah estetis tertentu sehingga menjadi bermakna sebagai bahasa ungkap dari pengalaman artistik maupun ideologi pelukisnya. Karena lukisan sebagai karya seni yang bersifat pribadi maka penampilannya akan menjadi unik dan karakteristik sesuai dengan kreativitas dan kepribadian masing-masing penciptanya.

\section{Simbolisasi Lukisan}

Melalui simbol-simbol dalam lukisan maka berbagai perasaan dan makna dapat ditangkap oleh apresian. K. Langer menyatakan bahwa :

Simbol tidak mewakili objek. Dalam membicarakan mengenai sesuatu, yang dibicarakan adalah konsep mengenai sesuatu itu, dan bukan sesuatu itu sendiri ; dan semua ini tentang konsep, bukan sesuatu itu, simbol-simbol harus diartikan. Bilamana sebuah simbol diungkapkan maka muncullah makna. (Jakob Sumarjo, $2014: 78)$.

Simbol-simbol dalam seni modern lebih bersifat individual sesuai dengan pengalaman dan kreativitas masing-masing namun dapat dipahami oleh semua orang. 
Karena pribadi yang terbentuk dengan kokoh dan kuat, dibina oleh unsur internal dan eksternal atau dengan kata lain unsur subjektif dan objektif, maka para seniman bermutu akan menghasilkan karya-karya yang khas pribadi dengan simbol-simbol yang pribadi pula yang ditemukan dalam perambahan kesenirupaannya. Tetapi hidup objektif dan kemasyarakatannya pula secara wajar simbol-simbol itupun bisa ditangkap orang sekelilingnya ; simbol-simbol itu secara wajar menjadi komunikatif (Sudarmaji, 1979:27).

Simbolisasi dalam lukisan merupakan representasi dari emosi dan ide-ide sehingga nilai simbolik sebuah lukisan terjadi dari pengalaman emosional melalui ungkapan garis, warna, bentuk dan kompisisi. Simbolisasi dalam lukisan adalah realitas dan subjektivitas batin pelukisnya.

\section{Bentuk Lukisan}

Sebuah lukisan dapat dilihat dan dinikmati pertama kali dari aspek bentuknya. Bentuk adalah yang bersifat inderawi atau kasat mata (Soedarso Sp, 2006:129). Bentuk merupakan totalitas karya lukisan yang terwujud secara fisik dengan berbagai unsurnya. Suatu hal yang menjadi penting dalam bentuk lukisan adalah penggunaan unsur fisik kesenirupaan berupa garis, warna, dan tekstur secara keseluruhan tersusun selaras dan berpadu sebagai kekuatan-kekuatan untuk mewujudkan aspek bentuk objek yang idiil menjadi yang sensuil sehingga bernilai dan bermakna baru.

\section{Penggubahan Bentuk Objek}

Lukisan merupakan suatu sarana curahan perasaan dan emosi pribadi sesuai dengan kecerdasan dan kreativitas pelukisnya. Lukisan sebagai bentuk bermakna ditangkap oleh indera penikmat serta merta dapat menggerakkan potensi emosinya. Lukisan mempunyai bentuk bermakna kalau emosi yang dibangkitkannya benar-benar emosi baru, segar, unik dan karakteristik. Penggubahan bentuk dalam lukisan merupakan salah satu cara untuk memperoleh nilai baru yang dapat membangkitkan emosi tertentu. Melalui proses penggubahan, seniman dapat mengolah dan memperlakukan bentuk objek secara bebas, tidak terkekang oleh masalah proporsi, prespektif dan volume keruangan. Dalam realisasinya tidak menutup kemungkinan terjadinya peluang pengembangan sesuai dengan kreativitas masing-masing.

Bentuk dapat digubah atau diciptakan mengikuti naluri imajiner yang ideal dengan berbagai kemungkinan cara, antara lain dengan stilasi, distorsi maupun deformasi. Stilasi, adalah pengembangan bentuk-bentuk di alam dalam seni untuk disesuaikan dengan suatu bentuk artistik atau gaya tertentu, seperti banyak terdapat dalam seni hias atau ornamentik (Soedarso Sp, 2006:82). Distorsi, adalah perubahan bentuk, penyimpangan, keadaan yang dibengkokkan. Menurut penjelasan Soedarso Sp (2006:82) bahwa "distorsi”, ialah penyimpangan atau pemutar balikan (bentuk, kenyataan dan lain-lain) baik secara intensional maupun tidak. Distorsi yang intensional misalnya bentuk wayang kulit purwa yang merupakan pemutarbalikan bentuk asalnya, manusia yang wajahnya digambarkan tampak samping, bahunya tampak depan, perutnya kembali tampak samping. Distorsi yang tidak intensional, terjadinya karena sesuatu yang tidak dimaksudkan oleh seniman 
seperti yang terjadi karena hukum perspektif sehingga yang jauh menjadi lebih kecil ukurannya, garis-garis yang sejajar dan menjauh menjadi tidak sejajar lagi.

Deformasi, adalah perubahan susunan bentuk yang dilakukan dengan sengaja untuk kepentingan seni, yang terkesan sangat kuat atau besar sehingga kadang-kadang tidak lagi berwujud figur semula atau yang sebenarnya. Sehingga hal ini dapat memunculkan figur atau karakter baru yang lain dari sebelumnya. Istilah distorsi berasal dari bahasa latin deformare yang artinya meniadakan atau merusak bentuk sehingga bentuk yang terjadi jauh bedanya dengan bentuk aslinya. Maka apabila stilasi masih berurusan dengan bentuk dasar yang diubah, deformasi sudah tidak menghiraukan lagi bentuk dasar tersebut (Soedarso Sp, 2006:82).

\section{Teknik}

Ketika seniman mempunyai gagasan, maka perlu dipikirkan bagaimana cara mewujudkan idenya tersebut, atau cara mentransformir wujud yang idiil menjadi wujud yang sensuil, yaitu dari sifat fisik menjadi psikis dan menyentuh perasaan manusia sehingga sebuah karya seni bisa bernilai tinggi. Teknik untuk mewujudkan karya, antara lain dalam bentuk pengolahan bahan dengan cara-cara khusus, seperti teknik dusel dan teknik arsir untuk gambar, teknik kuas kasar, teknik palet, teknik transparan dan teknik pointilis untuk seni lukis dan teknik-teknik lainnya (Nooryan Bahari, 2008:24).

Karena itulah kualitas artistik capaian bentuk lukisan akan sangat dipengaruhi dari unsur teknik yang berhubungan erat dengan ketepatan pemilihan dan kemampuan mengolah, menggunakan serta penguasaan karakteristik dari setiap jenisnya.

Bahan tinta berbeda dengan pensil, sifat dari goresan tinta (ballpoint) akan memberikan efek goresan yang berbeda bila dibandingkan dengan efek yang dibuat dengan pensil. Karena perbedaan itulah maka pemilihan jenis dan ukuran alat tentu harus disesuaikan sehingga menghasilkan efek artistik yang menarik dan menyatu. Setelah memahami mengenai tinta (ballpoint) dan pensil dengan berbagai kemungkinan penggunaannya maka tinta (ballpoint) dan pensil dapat diperlakukan dengan cara tertentu yang sifatnya subjektif dan kreatif.

Eksperimen merupakan hal yang penting karena dengan percobaan yang berulangulang maka kemungkinan akan diperoleh temuan-temuan baru. Untuk memperoleh efek artistik perlu menjelajahi kemungkinan-kemungkinan percampuran karkter yang berbeda, penggunaan bahan kanvas dengan tingkat kehalusan yang berbeda, warna digosok atau didusel, arsiran tumpang tindih, sekali jadi atau dikerik dan lain sebagainya secara kreatif bahkan tidak bertolak dari aturan dan sifat bahan yang sering membatasi gerak.

Eksperimen dilakukan secara kreatif akan menghasilkan penemuan-penemuan baru untuk mengembangkan kekuatan ekspresinya.

Penguasaan teknik pada setiap jenis bahan dan alat apapun akan tercermin dari kemampuan dan kemahiran seseorang menguasai karakter dari masing-masing bahan-alat untuk menghasilkan efek artistik dalam setiap karya yang dibuat. Pemilihan yang tepat pada bahan-alat serta menguasai sepenuhnya cara penggunaannya akan menghasilkan karya lukisan yang berkualitas. 


\section{Tema}

Melukis mengandung makna mewujudkan sesuatu dengan sesuatu yang sudah ada. Tema merupakan hal yang penting sehingga sesuatu yang lahir adalah sesuatu yang memiliki arti dan nilai baru. Tema merupakan gagasan yang dikomunikasikan pencipta karya seni kepada khalayak. Tema bisa saja menyangkut masalah sosial, budaya, religi, pendidikan, politik, pembangunan dan sebagainya (Nooryan Bahari, 2008:22).

Karya lukisan merupakan manifestasi dan penemuan diri sendiri. Seseorang yang mempunyai temperamen yang keras menyentak semes- tinya nampak pula pada pemilihan dan pengolahan tema (Sudarmaji, 1979:29). Yang menjadi penting dalam hal ini adalah sejauh mana tema tersebut mampu menyentuh penikmat lukisan, baik pada nilai-nilai tertentu dalam kehidupan sehari-hari ataupun hal-hal yang bisa mengingatkan pada peristiwa-peristiwa tertentu.

Kehidupan sosial politik kekinian adalah salah satu pilihan tema yang menarik sebagai bagian kehidupan seniman bermasyarakat dan sekaligus untuk menjawab dan menanggapi penyimpangan kehidupan pada zamannya melalui ungkapan estetik. Masyarakat sebagai objek terdiri dari individu-individu maupun kelompok-kelompok manusia yang saling berhubungan antara satu dengan lainnya. Proses hubungan itulah merupakan proses sosial karena di dalam- nya terjadi aktivitas interaksi sosial. Menurut M. Jazuli (2014:1) dijelaskan bahwa :

"Masyarakat adalah sebentuk tatanan yang mencakup pola-pola interaksi antar manusia yang berulang secara konstan. Sungguhpun tatanan itu tidak selalu pasti tidak ada konflik atau pertentangan dengan kadar yang bervariasi itu tetap harus dipolakan agar membentuk bagian dari sebuah masyarakat".

Keterlibatan masyarakat yang berkait dengan aktivitas interaksi manusia sehari-hari dalam kehidupan bersama inilah yang dimaksudkan sebagai tema sosial. Di sisi lain ada aktivitas interaksi yang lebih khusus yaitu kehidupan politik yang bermakna "tata kelola hidup bersama" (E. Armada Riyanto CM, 2015 : 14). Dunia politik memang dekat dengan kenaifan, kata Nietzsche: "politik ada dalam ranah kekuasaan. Siapa menang, berkuasa. Siapa kalah pecundang. Habis perkara" (E. Armada Riyanto CM, 2015 : 15)

Isu-isu kehidupan sosial politik yang menyimpang akhir-akhir ini sungguh memprihatinkan dan menarik untuk di respon sebagai tema dalam proses penciptaan seni. Selain sebagai poses berekspresi, melukis dapat menjadi bentuk kepedulian seniman dalam hidup bermasyarakat.

\section{Isi}

Isi adalah apa yang ada dibalik yang kasat mata (Soedarso Sp, 2006:129). Dalam isi seorang seniman menunjukkan daerah perhatian atau minatnya. Isi adalah persoalan intiusi dan emosi seniman (Soedarso Sp, 2006:131). Menurut Eugene Veron (dalam Sodarso Sp, 2006:129) masalah kehebatan suatu lukisan bukanlah dilihat dari apakah karya itu menyenangkan atau tidak, melainkan dari seberapa dalamkah gerangan kehidupan jiwa 
yang diekspresikan itu berasal. Seni yang besar adalah seni yang merupakan gaung jiwa yang besar, ditambah, tentu saja, dengan cara-cara visualisasi yang efisien dan mudah terbaca. Sebuah lukisan yang baik memberi banyak kemungkinan kepada pengamatnya untuk membuat lebih banyak interpretasi, sehingga penciptaan dalam lukisan mengandung makna mewujudkan sesuatu dengan sesuatu yang sudah ada. Tetapi sesuatu yang lahir, adalah sesuatu yang punya arti dan nilai baru.

Pengembangan nilai estetika dalam kerangka yang lebih luas, bermakna pula proses pembelajaran. Akibat pengaruh unsur provokatif yang dapat dipahami sebagai upaya peningkatan kualitas hidup manusia, kehadiran sebuah lukisan tidak sekedar dipahami dan dinikmati tetapi lebih dari itu perlu ditinjak lanjuti dengan berbuat sesuatu yang lebih bermanfaat untuk kehidupan bersama.

Makna lain, suatu pengambilan tindakan untuk memilah unsur-unsur positif dari unsur-unsur yang negatif adalah proses penyadaran yang dapat dilakukan melalui perenungan dan sikap kritis terhadap fenomena yang terjadi. Penyadaran terhadap sesuatu penyimpangan dalam kehidupan sosial politik pada hakikatnya terjadi proses keterlibatan dan kontribusi dalam pemberdayaan masyarakat yang apresiatif, kritis, demokratis dan bertanggung jawab.

\section{Landasan Penciptaan}

Jika mengamati sebuah karya lukisan tentang seorang manusia, mungkin yang terlihat sifat-sifat pada objek tersebut. Misalnya dapat dilihat jenis orang laki-laki, badan besar, wajah tampan, tegar dan berwarna gelap. Apa yang terlihat hanyalah sebuah kualitas objek dengan sifat-sifat tertentu yang merupakan informasi atau penampilan verbal saja.

Menurut Jakob Sumardjo (2000:54) seni memang juga bertujuan memberikan pemahaman, bukan secara nalar, verbal, tetapi secara empirik, pengalaman dan penghayatan. Jadi, jelaslah bahwa seni bukan sekedar informasi mengenai kenyataan fakta belaka tetapi lebih dari itu kualitas yang dirasakan melalui penghayatan dan pengalaman seniman setelah berhadapan dengan objek merupakan nilai kualitas yang sebenarnya yang diwujudkan dalam karya lukisan.

Mungkin dari objek tersebut mengingatkan kondisi seseorang yang terhormat, figur publik, masih muda namun perilakunya ngawur, rakus dan arogan. Ada sesuatu realita yang bertentangan di balik dunia permukaan. Nilai-nilai kualitas demikian perlu disampaikan kepada orang lain karena maknanya sungguh bermanfaat sebagai pembelajaran dan penyadaran sosial. Untuk mencapai maksud yang demikian maka seniman harus menaklukkan kualitas yang dirasakannya dengan media dan teknik yang dipilihnya sehingga terjadi perwujudan seni lukis yang berarti. Perwujudan seni juga dapat disebut sebagai representasi (Jakob Sumardjo, 2000:76). Disebut representasi karena memang dalam prosesnya seniman bersinggungan dengan kenyataan objektif di luar dirinya atas kenyataan subjektif dalam dirinya sendiri sehingga menimbulkan respon yang diungkapkan dalam karya lukisan.

Seorang seniman suatu saat menciptakan tidak sekedar memenuhi hasrat estetiknya saja, tetapi karena didorong oleh munculnya berbagai keresahan dan kejanggalan dalam kehidupan di lingkungannya. Berbagai kegelisan membuat jiwanya terganggu yang 
mendorong niat untuk berbuat lewat karya seninya. Karya seni itu merupakan usaha menjawab atau menanggapi kejanggalan kehidupan pada zamannya melalui ungkapan estetik. Dengan dukungan kreativitas dalam seni dapat memungkinkan ditemukannya berbagai cara pengucapan baru, antara lain melalui penggubahan unsur bentuk dalam lukisan. Penggubahan bentuk dengan berbagai cara, media dan teknikyang dipilih dapat membangun emosi artistik, yang segar unik dan karakteristik.

Bagaimana seniman mencipta karya seni tentu selalu terkait dengan orang lain atau dengan masyarakat lingkungannya. Menurut Jakob Sumardjo (200:94) seniman itu makhluk sosial dan memiliki status dan tempat dalam masyarakat karena arti diri yang diberikan kepada masyarakatnya. Apa yang dilakukan tetap untuk masyarakatnya entah itu memiliki kegunaan praktis maupun esensi. Maka jika penggubahan bentuk diaplikasikan untuk provokasi visual terkait dengan tema-tema kekinian yang mengesankan kondisikondisi sensitif seperti kesakitan, tertindas, kekerasan, keserakahan, arogan, diskriminasi, penganiyayaan atau pelecehan sebagai aksi dan reaksi tertentu dapat menimbulkan rangsangan bagi seseorang dan masyarakat untuk membangun pemahaman bersama dan sebagai pembelajaran serta penyadaran sosial, kemudian berbuat sesuatu yang diyakini bermanfaat dalam kehidupan bersama.

\section{Proses}

Pada awalnya saya berpikir, mungkinkah melukis dapat merupakan proses pembelajaran dan penyadaran tentang realitas kehidupan manusia yang memungkinkan bersentuhan dengan cara merasa, berpikir, bersikap dan bertindak, baik secara individual maupun sosial. Berbagai permasalahan muncul silih berganti mengganggu kondisi kehidupan masyarakat. Hal ini merupakan ide dasar proses penciptaan karya lukisan dengan tema kekinian tentang realitas yang terjadi di balik dunia permukaan. Fenomena kehidupan dengan kondisi yang menggelisahkan menggiring imajinasi saya sebagai rangsang cipta dan penuntun perencanaan penciptaan lukisan dari awal sampai akhir.

Visualisasi lukisan tidak imitatif tetapi lebih bebas dengan proses eksplorasi penggubahan bentuk-bentuk agar diperoleh hasil imajinatif, idealis, simbolis dan karakteristik. Berbagai bentuk penggubahan diperoleh dengan cara stilasi, distorsi maupun deformasi sehingga diperoleh bentuk-bentuk imajinatif baru untuk mewakili ide dan emosi artistik. Penggabungan berbagai unsur bentuk gubahan dengan unsur-unsur lain sesuai tema tertentu melalui goresan skets sebagai proses awal visualisasi lukisan dengan mempertimbangkan tata letak yang sesuai, menarik, seimbang, proporsional dan menyatu. Agar efek visualisasi menjadi lebih dramatik dan artistik maka pengaplikasian teknik arsir dilakukan secara kreatif bahkan tidak bertolak dari aturan konvensional yang membatasi gerak sambil mengamati efek yang timbul, mengarahkan dan mengolah efekefek tersebut sampai diperoleh detail dan kebermaknaan yang diinginkan serta totalitas yang betul-betul selesai.

Kehidupan seni tidak begitu saja diakhiri setelah penciptaanya selesai. Seniman, karya seni dan penghayat merupakan tiga komponen penting dalam kehidupan seni, sehingga penyelenggaraan pameran mutlak diperlukan sebagai bentuk aktivitas yang memungkinkan terjadinya interaksi ketiga komponen tersebut. Pameran dirancang 
sedemikian rupa agar dapat menemukan makna sebagai ajang dialog yang kreatif, artistik dan demokratis serta memiliki nilai psikologis dalam bentuk pembelajaran dan penyadaran sosial sekaligus sebagai semacam catatan yang merefleksikan kenyataan kehidupan manusia pada zamannya.

\section{Karya}

Karya lukisan diciptakan melalui proses tahapan yang dimulai dengan pengamatan dan pemaknaan objek sesuai tema ketimpangan dalam kehidupan sosial politik, selanjutnya eksplorasi pengolahan dan penciptaan bentuk-bentuk simbolik diungkapkan dengan media tinta pada kanvas menggunakan teknik arsir. Selain sebagai pengungkapan nilai ekspresi lukisan dapat bernilai provokatif yang memungkinkan dapat berfungsi sebagai pembelajaran dan penyadaran kehidupan sosial politik masyarakat pada zamannya.

\section{Lukisan "Terjerat"}

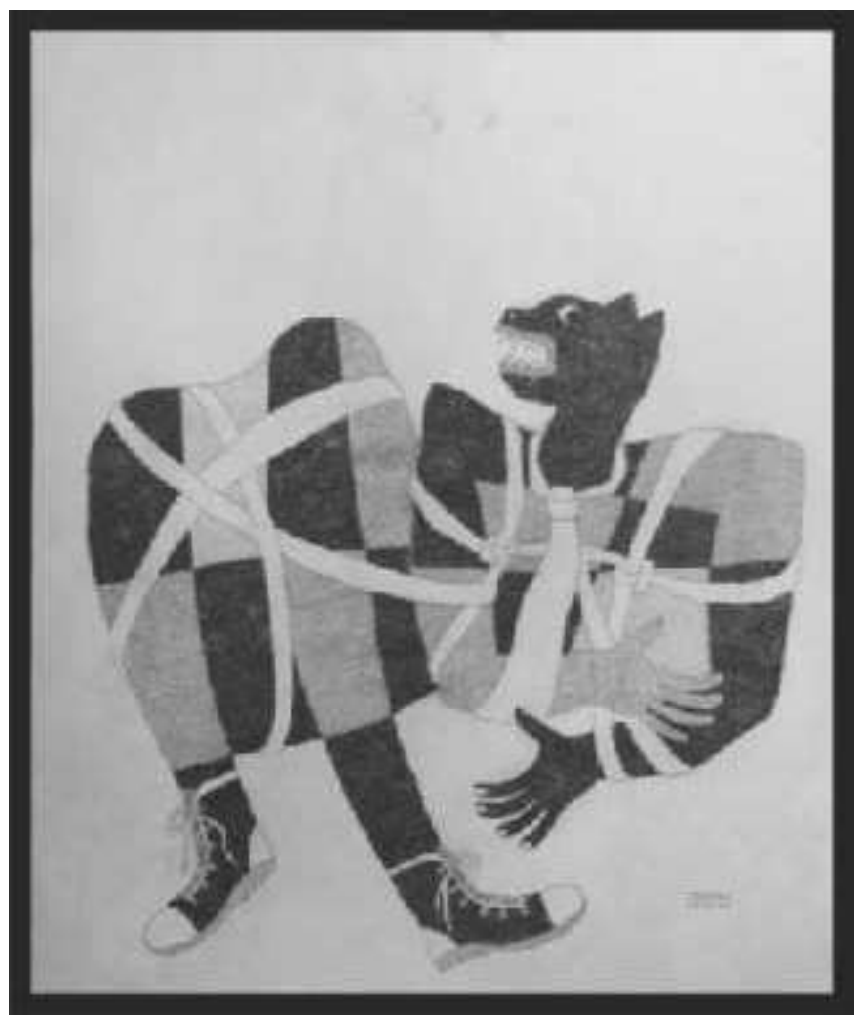

Sebuah lukisan berukuran 120X100 cm berjudul "Terjerat" menggunakan bahan tinta pada kanvas dengan teknik arsir. Penampilan bentuk figur tampak terjerat oleh dasi yang memanjang melilit tubuh dan tangannya. Terasa ekspresi meronta, bentuk kepala menyerupai binatang buas yang mulutnya menganga dan kedua kaki bersepatu posisi menjulur ke bawah menahan kekuatan.

Lukisan "Terjerat" berusaha mengungkapakan realitas kehidupan sebagian orang khususnya oknum penguasa yang identik dengan atribut dasinya. Figur yang terjerat 
pelanggaran hukum namun tetap menantang tanpa merasa salah, menggambarkan misteri seorang penguasa yang terpidana namun tidak pernah menunjukkan rasa malu dan tanpa penyesalan. Ada nilai provokatif dalam lukisan untuk pemaknaan atas realitas kejahatan oknum penguasa.

Penikmat (apresian) tidak sekedar paham terus selesai, lebih dari itu mereka dapat memaknai sebab akibat suatu kasus sebagai pembelajaran dan penyadaran kehidupan masyarakat. Dari proses pembelajaran dan penyadaran demikian dapat berlanjut sebagai rangsang tindakan untuk lebih berhati-hati dalam proses pemilihan pemimpin dan penguasa di masa yang akan datang.

\section{Lukisan "Wakil Rakyat"}

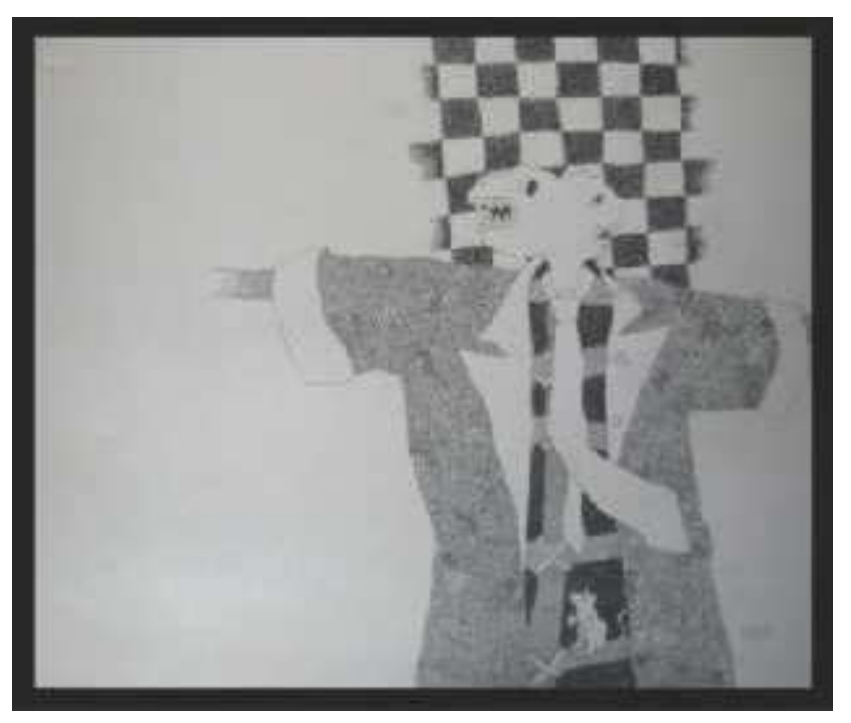

Sebuah lukisan berukuran 100X120 cm berjudul "Wakil Rakyat" menggunakan bahan tinta pada kanvas dengan teknik arsir. Penampilan bentuk figur memedi manuk di sawah memakai atribut pakaian model jas dengan posisi lengan tergulung dan berdasi. Bagian atas berwujud kepala berwajah dua yang berbeda wujud dan karakternya. Kotakkotak hitam putih semacam papan catur berfungsi sebagai latar belakang. Bagian bawah ada seekor tikus dengan posisi jongkok misterius.

Lukisan "Wakil Rakyat" terasa berangkat dari keprihatinan sosial atas ketimpangan yang terjadi karena adanya oknum wakil rakyat yang munafik. Sikap tidak amanah ditujukkan dengan berbagai perilaku yang ingkar janji, rakus, korupsi, tidak membela rakyat, bahkan sering melakukan penindasan, pemaksaan dan menakut-nakuti rakyat. Dunia politik sebagai arena pertandingan untuk mencari kemenangan kepentingan dan kekuasaan.

Nilai-nilai provokasi visual diperoleh dalam lukisan ini melalui pengungkapan figur dengan bentuk sedemikian rupa yang dapat dimaknai sebagai representasi kebobrokan moral wakil rakyat yang ternyata tidak sesuai dengan harapan masyarakat. Sebuah lukisan bernilai provokatif memungkinkan dapat mempengaruhi timbulnya sikap solidaritas sosial untuk membangun pemaknaan bersama atas ketimpangan dalam kehidupan dan 
mendorong untuk berbuat sesuatu yang dapat diyakini bermanfaat dalam kehidupan bersama.

\section{Kesimpulan}

Realitas kehidupan dengan berbagai permasalahan silih berganti. Hati menjadi resah ketika membaca koran karena di beberapa halamannya memuat berbagai peristiwa penyimpangan dalam kehidupan sosial politik di negeri ini. Berbagai penyimpangan nilainilai moral dan etika kemanusiaan menjadi kasus kegelisahan yang menarik direspon sebagai tema penciptaan lukisan yang kreatif dan kritis.

Proses visualisasi lukisan dilakukan melalui beberapa tahapan yang diawali dengan pengamatan dan pemahaman objek sesuai dengan tema ketimpangan atau penyimpangan dalam kehidupan sosial politik. Selanjutnya eksplorasi pengolahan dan pencapaian bentuk-bentuk simbolik yang provokatif melalui proses penggubahan dilakukan dengan cara-cara deformasi, stilasi ataupun distorsi diungkapakan dengan media tinta pada kanvas. Penggunaan media tinta diatas kanvas dilakukan dengan teknik arsir yang bervariasi. Berbagai kemungkinan teknik arsir diolah dan dipadukan dengan penerapan prinsip-prinsip penyusunan secara kreatif untuk pencapaian berbagai kemungkinan efek artistik dan jangkauan nilai ekspresif yang unik dan karakteristik.

Lukisan dengan berbagai unsur bentuk simbolik provokatif selain bernilai ekspresif dapat mengandung makna yang lebih luas untuk memberi peluang kepada penikmat untuk lebih banyak berintepretasi. Nilai provokasi visual dalam lukisan tidak sekedar hanya untuk dipahami dan dinikmati, tetapi lebih dari itu perlu ditinjaklanjuti dengan berbuat sesuatu yang diyakini lebih bermanfaat dalam kehidupan bermasyarakat.

Proses interaksi antara seniman dan masyarakat melalui media lukisan yang bernilai provokatif memungkinkan dapat menimbulkan daya rangsang untuk bertindak sesuatu. Melalui proses pengamatan, pemahaman dan penikmatan terhadap lukisan ada keterlibatan dan pemberdayaan sifat-sifat apresiatif, kritis, demokratis dan tanggung jawab pada diri apresian. Keterlibatan dan pemberdayaan sifat-sifat demikian bermakna pula sebagai proses pembelajaran yaitu adanya peningkatan kualitas sumber daya manusia. Sifat-sifat kritis, demokratis dan tanggung jawab bermakna pula sebagai kemampuan untuk mengambil tindakan dengan memilah unsur-unsur positif dari unsur-unsur negatif melalui perenungan atas berbagai penyimpangan kehidupan sosial politik. Proses pengambilan tindakan memilah unsur-unsur positif dari unsur-unsur negatif inilah yang bermakna sebagai proses penyadaran.

\section{KEPUSTAKAAN}

Ardiansyah, Andre.Pocket Dictionary. Surabaya :Pustaka Agung Harapan

Armada Riyanto, E. 2011. Berfilsafat Politik. Yogyakarta : Kanisius

Bahari, Nooryan. 2008. Kritik Seni Wacana Apresiasi dan Kreasi. Yogyakarta : Pustaka Pelajar

Dwi Marianto, M. 2011. Menempa Quanta Mengurai Seni. Yogyakarta : BP ISI Yogyakarta 
Hauskeller, Michael. 2015. Seni-Apa Itu? Posisi Estetika dari Platon sampai

Danto. Yogya- karta : PT Kanisius

M. Jazuli. 2014. Sosiologi Seni. Yogyakarta : Graha Ilmu

Sachari, Agus.2002. Estetika Makna, Simbol dan Daya. Bandung : ITB

Soedarso Sp. 2006. Trilogi Seni Penciptaan Eksistensi dan Kegunaan Seni. Yogyakarta : BP ISI Yogyakarta

Sudarmaji. 1979. Dasar-Dasar Kritik Seni Rupa. Jakarta : Pemerintah DKI Jakarta Dinas Museum dan sejarah

Sumardjo, Jakob. 2000. Filsafat Seni. Bandung: ITB Sumardjo, Jakob. 2014. Estetika

Paradoks. Bandung : Kelir Kedaulatan Rakyat. Edisi 11 Juli 2011 Kedaulatan

Rakyat. Edisi 5 Mret 2015

Kompas. Edisi 4 Oktober2014

Kompas. Edisi 7 Desember 2014

Kompas. Edisi 22 Februari 2015

Republika. Edisi 2 Maret 2015 